10IKC-143

\title{
ROLE OF SEDIMENT DERIVED CARBONATITIC MELTS IN ORGIN OF HIGH-K MANTLE DOMAINS
}

\author{
A. Golubkova and M.W. Schmidt \\ Institute of Geochemistry and Petrology, ETH Zurich, Switzerland
}

\section{INTRODUCTION}

Partial melting of metasomatized carbonated mantle peridotites was proposed as a mechanism for formation of many alkali- and $\mathrm{CO}_{2}$-rich silicaundersaturated rocks. Carbonatite melts were considered as one of the possible metasomatic agents operating within the Earth owing to their favorable physical properties (e.g., Dobson et al., 1996) and on the basis of mineralogical (the presence of carbonate inclusions in diamonds, e.g., Zedgenizov et al., 2004) and geochemical observations (enrichment of mantlederived melts and minerals in incompatible elements). Potassic magmas varying from lamproites, leucitites, orangeites to group II kimberlites testify for the significant role of potassium in many mantle melting environments. In this study we focus on the processes leading to the formation of $\mathrm{K}_{2} \mathrm{O}$-rich mantle domains which must form the source regions of above magmas. Up to now there are many published experimental studies on the melting behavior of different model and natural systems within the wide P-T interval, which resulted in the appearance of carbonatite melts. Involvement of crustal components in mantle processes was verified by a number of geochemical studies (e.g., Stracke et al., 2005). In particular, the geochemistry of some K-rich rocks (Avanzinelli et al., 2008) also bears evidence for the presence of subducted material in their source regions. Previous studies (Thomsen and Schmidt, 2008; Grassi and Schmidt, 2011 a, b) demonstrated that among the subducted lithologies carbonated pelites have the lowest melting temperatures at $>5 \mathrm{GPa}$. The depth interval of 8-15 GPa corresponds to an ultra-potassic nature of the partial carbonatite melts formed in such pelites. Once being formed, such melts will escape their slab source region and migrate into the mantle. Chemical disequilibrium between such oxidized alkaline low $\mathrm{X}_{\mathrm{Mg}}$-melts and high- $\mathrm{X}_{\mathrm{Mg}}$, olivine (-polymorph)-saturated, reduced mantle triggers metasomatic redox reactions to proceed, modifying the mantle mineralogy. In the vicinity of the slab or in regions of high carbonatite flow, oxygen fugacity values will be dominated by the carbonatite melt and allow for the presence of solid carbonates or carbonate melts at least partially equilibrated with the mantle. The resulting metasomatized mantle peridotite will be $\mathrm{K}$ rich and have solid carbonates in subsolidus assemblage. With increasing depth in the mantle oxygen fugacity decreases to values close to or below the IW equilibrium. In such regions carbonatite melts will be "redox" frozen after interaction with the volumetrically dominating metal-bearing mantle. The mineralogy of such resulting mantle domains will differ from the situation described above, diamond will become the major carbon mineral and alkali-bearing silicates will be the main hosts of potassium depending on the total alkali content. In our experiments we simulate both scenarios in which oxygen fugacity is dominated by the carbonatite, and one where oxygen fugacity is dominated by ambient mantle, through a series of redox reactions between sediment derived carbonatite melts and mantle peridotites.

\section{EXPERIMENTAL AND ANALYTICAL TECHNIQUE}

To simulate metasomatic reactions in this study we used at each pressure the adequate composition of carbonatite melts as obtained at the solidus of anhydrous carbonated pelites at 8 and $13 \mathrm{GPa}$ (Grassi and Schmidt, 2011). The composition of KLB-1 spinel lherzolite (Takahashi, 1986) was taken as an approximation of fertile mantle on the basis of the relatively low $\mathrm{Mg} /(\mathrm{Mg}+\mathrm{Fe})$ ratio of olivine and $\mathrm{Cr} /(\mathrm{Cr}+\mathrm{Al})$ ratio of spinel. Furthermore, the carbonatites were also equilibrated with a model harzburgitic depleted mantle composed of a mixture of olivine and orthopyroxene in the proportion of 60:40 consistent with the average composition of harzburgite xenoliths and published depleted mantle estimates (Salters and Stracke, 2003). All mixtures were prepared using powders of synthetic and natural (San Carlos 


\section{$10^{\text {th }}$ International Kimberlite Conference, Bangalore - 2012}

olivine, orthoenstatite from Kilosa, Tanzania, siderite from Greenland) materials. Fayalite and wollastonite were synthesized at $1 \mathrm{~atm}$. Each compound was dried at appropriate temperatures and time before mixing and then carefully grinding under acetone to obtained fine grained ( $<10$ micron) homogeneous mixtures. Welded $\mathrm{Au}_{80} \mathrm{Pd}_{20}$ capsules were employed under oxidizing conditions to avoid the loss of iron. After many failed attempts with different materials and configurations (Mo, W) we settled for solid Fe capsules to simulate a reducing environment. In the latter case the starting composition was modified such that all carbon in the system was already present as graphite. Ir powder was added as a redox sensor (Woodland and O'Neill, 1997) and oxygen fugacity was calculated on the basis of $\mathrm{X}_{\mathrm{Fe}}$ in periclase and the Ir-Fe alloy (Frost, 2003; Mukhopadhyay et al., 1993; Swartzendruber, 1984).

All experiments were carried out in a Walkertype multi anvil high-pressure apparatus (600- and 1000 -ton presses). The 600-ton press was rotated every 10 min during the experiments. WC anvils with 11 and $8 \mathrm{~mm}$ truncation edges lengths were used with standard 10 and $14 \mathrm{~mm} 95 \% \mathrm{MgO}+5 \% \mathrm{Cr}_{2} \mathrm{O}_{3}$ octahedra for the experiments at 8 and $13 \mathrm{GPa}$, respectively. Heating assemblies included a $\mathrm{ZrO}_{2}$ sleeve, a stepped $\mathrm{LaCrO}_{3}$ heater, $\mathrm{MgO}$ inner sleeves and Mo disks. Natural pyrophyllite was employed as a gasket material. Temperature was controlled with a B-type thermocouple $\left(\mathrm{Pt}_{94} \mathrm{Rh}_{6} / \mathrm{Pt}_{70} \mathrm{Rh}_{30}\right)$ and no correction for the effect of pressure on thermocouple emf was applied. Run times of experiments necessary to obtain texturally equilibrated charges in presence of carbonate melts were between 12 and $24 \mathrm{hrs}$ and homogeneous mineral compositions testify for equilibration of experimental products. In order to attain equilibrium in experiments with $\mathrm{Fe}$ capsules and graphite/diamond, run time was increased to 4 days. Nevertheless, mineral compositions were still somewhat variable within some charges and textures did not demonstrate complete equilibration.

Textural observations of run products were performed using a JEOL JSM6300 field emission SEM with EDS detector; while the chemical composition of minerals and melts was obtained using a JEOL JXA8200 electron microprobe with an acceleration voltage of $15 \mathrm{kV}$. Counting times for peaks and backgrounds were 20 and $10 \mathrm{~s}$ for silicate minerals and 10 and $5 \mathrm{~s}$ for carbonates. A focused electron beam was used for silicates. For melts and carbonates a defocused beam was employed $(2-10 \mu \mathrm{m}$, beam diameter depending on on the size of phases) with a current of 2 and $6 \mathrm{nA}$, respectively. $\mathrm{Na}$ and $\mathrm{K}$ were analyzed first to avoid diffusional loses.

\section{EXPERIMENTAL RESULTS}

The experiments under oxidizing and reducing conditions yield two different mineral assemblages corresponding to two extreme scenarios when oxygen fugacity of the system is controlled either by carbonatite melt or metal-bearing mantle. With decreasing oxygen fugacity, carbonatite melt and solid carbonates convert into diamond and two different $\mathrm{K}$ bearing minerals in addition to garnet and clinopyroxene become the major hosts of alkalis.

\section{Experiments under oxidizing conditions}

Spinel lherzolite and harzburgite were transformed into carbonated wherlite after the interaction with carbonatite melt at 8 and $13 \mathrm{GPa}$ and $1100-1400{ }^{\circ} \mathrm{C}$ under oxidizing conditions. The oxygen fugacity of these experiments was estimated to be close to the CCO buffer. Silicates (garnet and clinopyroxene) after equilibration with cabonatite are characterized by higher $\mathrm{CaO}, \mathrm{TiO}_{2}$, and $\mathrm{Fe}_{2} \mathrm{O}_{3}$ contents in comparison with their composition in mantle peridotite at P-T conditions of interest (Takahashi, 1986; Akaogi and Akimoto, 1979).

Mineral assemblage at both studied pressures within this temperature interval included olivine + clinopyroxene + garnet $\pm \mathrm{Fe}$-Ti-oxide \pm carbonates (magnesite and/or K-Mg-carbonate). Carbonate melt was not observed at temperatures below $1200{ }^{\circ} \mathrm{C}$. Olivine is characterized by $\mathrm{Mg}$ \# of 0.91 , what is almost the same with respect to studies on the KLB-1 spinel lherzolite and natural garnet lherzolite at P-T conditions close to our experiments (Takahashi, 1986; Akaogi and Akimoto, 1979). Clinopyroxene is diopsidic in composition with $\mathrm{Mg}$ \# varying from 0.85 to 0.95 and with the high $\mathrm{Fe}_{2} \mathrm{O}_{3}$ concentration; clinopyroxene total alkali contents are always greater than 1 wt. \% with $\mathrm{Al}_{2} \mathrm{O}_{3}$ being lower than the average clinopyroxenes from peridotitic suites (fig. 1). $\mathrm{X}_{\mathrm{Ca}}$ of garnets are in the range from 0.20 to 0.40 and the fraction of $\mathrm{Fe}^{3+}$ in total iron (obtained through garnet-normalization) ranges between 0.32 and 0.72 at $13 \mathrm{GPa}$ and a bit lower values at $8 \mathrm{GPa}$. Majorite contents increase with pressure; $\mathrm{Na}$ and $\mathrm{K}$ apfu are highly variable. $\mathrm{TiO}_{2}$ contents are always higher than 2 wt. \%. On the basis of the classification scheme of Schulze (2003) for mantlederived garnets from kimberlites all garnets demonstrate strong affinity to the eclogitic $\mathrm{A}$ and $\mathrm{B}$ groups (<1 wt. $\% \mathrm{Cr}_{2} \mathrm{O}_{3}$ ); compositions with $\geq 1$ wt. $\%$ $\mathrm{Cr}_{2} \mathrm{O}_{3}$ and high $\mathrm{TiO}_{2}$ contents are close to garnet megacrysts found in kimberlites. 


\section{$10^{\text {th }}$ International Kimberlite Conference, Bangalore - 2012}

Under oxidizing conditions solid carbonates (magnesite and $\mathrm{K}-\mathrm{Mg}$-carbonate) coexist with melt until the complete solidification of melt. At this temperature $\mathrm{K}-\mathrm{Mg}$-carbonate becomes the dominant $\mathrm{CO}_{2}$-bearing mineral within the subsolidus assemblage. The composition of magnesite is on the $\mathrm{MgCO}_{3}-\mathrm{FeCO}_{3}$ join with $\mathrm{Mg}$ \# of 94 at $13 \mathrm{GPa}$ and 80 at $8 \mathrm{GPa}$. Alkali and $\mathrm{MnO}$ contents are negligible. $\mathrm{K}-\mathrm{Mg}$-carbonate (fig. 2, Table 1) has a composition, which strongly depends on temperature $(\mathrm{K}+\mathrm{Na} / \mathrm{Mg}+\mathrm{Ca}+\mathrm{Fe}+\mathrm{Mn}$ molar ratio changes from $<1$ at $1250{ }^{\circ} \mathrm{C}$ to $\sim 2$ at $1100{ }^{\circ} \mathrm{C}$ in the 13 $\mathrm{GPa}$ runs). Within the family of double carbonates, containing both alkalis and alkaline earth, the composition of these carbonates from our study is closest to $\mathrm{K}_{2} \mathrm{Mg}\left(\mathrm{CO}_{3}\right)$, which structure is identified as analogues to nyerereite (Simons and Sharma, 1983).

Residual and modified carbonate melts in equilibrium with the wherlitic assemblage have average $\mathrm{X}_{\mathrm{Ca}}=0.44$ and $\mathrm{Mg} \#$ of 87 at $13 \mathrm{GPa}$ and lower $\mathrm{X}_{\mathrm{Ca}}$ at 8 $\mathrm{GPa}(\sim 0.3)$ (fig. 3). $\mathrm{K}_{2} \mathrm{O} / \mathrm{Na}_{2} \mathrm{O}$ ratios are always greater than 1 but increase significantly at lower pressures $\left(\mathrm{K}_{2} \mathrm{O} / \mathrm{Na}_{2} \mathrm{O}>10\right)$. The equilibration with peridotite changed these melts compositions in the expected direction; $\mathrm{MgO}$ content increased, meanwhile, the concentrations of $\mathrm{Al}_{2} \mathrm{O}_{3}$ and $\mathrm{TiO}_{2}$ decreased. In comparison with partial melts from carbonated peridotites and eclogites, melts from this study demonstrate higher alkali contents, comparable only to those recently published by Brey et al. (2011) on the Krich carbonated peridotite.

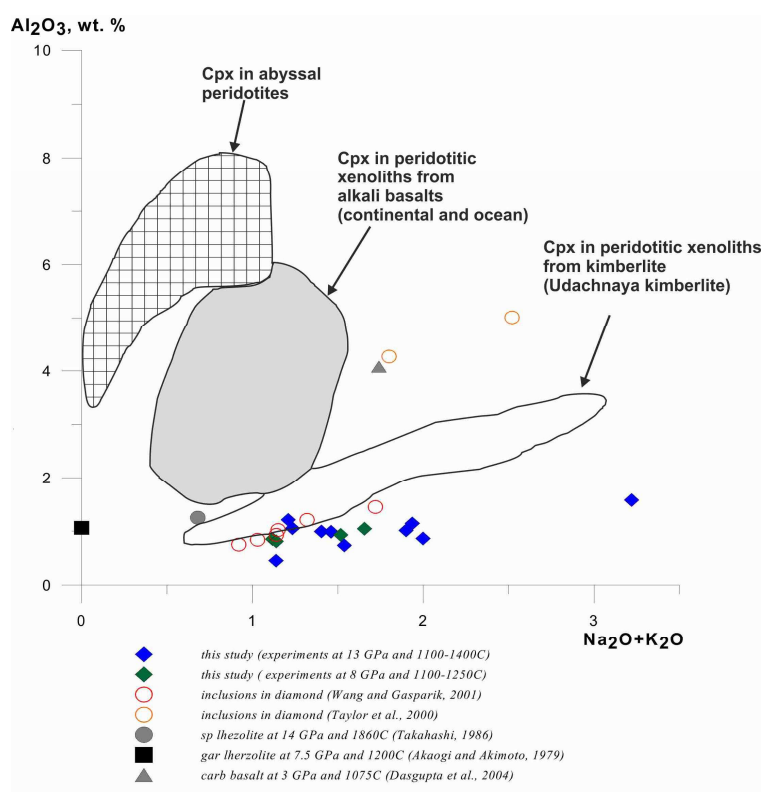

Fig. 1. Clinopyroxene compositions plotted in terms of $\mathrm{Na}_{2} \mathrm{O}+\mathrm{K}_{2} \mathrm{O}$ vs. $\mathrm{Al}_{2} \mathrm{O}_{3}$ (wt. \%). Compositional fields for peridotitic and eclogitic clinopyroxene after Wang and Gasparik (2001) and references within

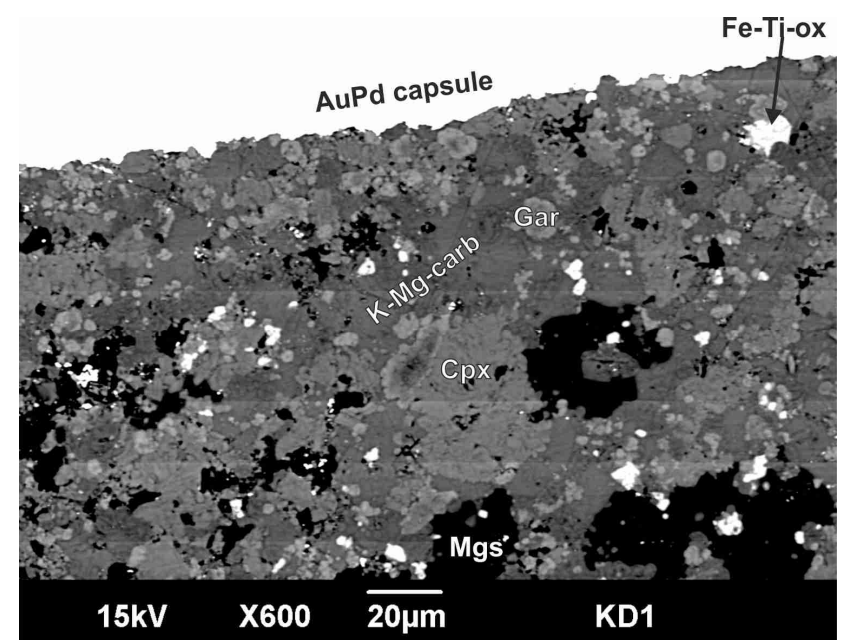

Fig. 2. Back-scattered electron image of experimental products at $8 \mathrm{GPa}$ and $1100{ }^{\circ} \mathrm{C}$ under oxidizing conditions; gar - garnet, cpx - clinopyroxene, mgs - magnesite, $\mathrm{K}-\mathrm{Mg}$ carb - K-Mg-carbonate, Fe-Ti-ox - Fe-Ti-oxide

Table-1. Composition of K-Mg-carbonates (wt. $\%)$ from this study; $\mathbf{1}$ - at $13 \mathrm{GPa}$ and $1100{ }^{\circ} \mathrm{C}, 2$ at $13 \mathrm{GPa}$ and $1250{ }^{\circ} \mathrm{C}, 3$ - at $8 \mathrm{GPa}$ and $1100^{\circ} \mathrm{C}$; $\mathrm{CO}_{2}$ content was calculated by stoichiometry

\begin{tabular}{|c|c|c|c|}
\hline & $\mathbf{1}$ & $\mathbf{2}$ & $\mathbf{3}$ \\
\hline $\mathbf{N a}_{\mathbf{2}} \mathbf{O}$ & 5.42 & 4.78 & 0.85 \\
\hline $\mathbf{K}_{\mathbf{2}} \mathbf{O}$ & 33.52 & 16.71 & 35.88 \\
\hline $\mathbf{C a O}$ & 1.34 & 23.29 & 1.74 \\
\hline $\mathbf{F e O}$ & 0.75 & 4.31 & 1.79 \\
\hline $\mathbf{M g O}$ & 18.09 & 9.01 & 19.02 \\
\hline $\mathbf{M n O}$ & 0.08 & 0.00 & 0.09 \\
\hline $\mathbf{C O}_{\mathbf{2}}$ & 40.80 & 41.80 & 40.63 \\
\hline $\mathbf{T o t a l}$ & 100.00 & 100.00 & 100.00 \\
\hline $\mathbf{X}_{\mathbf{C a}}$ & 0.05 & 0.60 & 0.06 \\
\hline
\end{tabular}

\section{Experiments under reducing conditions}

To model the situation where carbonatite melts can be "redox" frozen via a reaction with metal-bearing mantle, experiments were conducted in iron capsules at $13 \mathrm{GPa}$ and $1400{ }^{\circ} \mathrm{C}$. Oxygen fugacity estimates resulted in $\Delta \log f \mathrm{O}_{2}[\mathrm{IW}] \sim-1$. Even though experimental results did not demonstrate complete equilibration, on the basis of a few pilot experiments of Grassi (2010) and our runs employing the $\mathrm{Mo}-\mathrm{MoO}_{2}$ oxygen buffer, we can assume that at these conditions olivine, garnet, clinopyroxene, periclase, phase $\mathrm{X}$ (in our case, the composition of $\mathrm{K}-\mathrm{Mg}$-silicate is close to the formula of anhydrous phase $\mathrm{X}$ with significant $\mathrm{Na}_{2} \mathrm{O}$ contents) and diamond is the stable mineral assemblage. In addition to phase $\mathrm{X}$, another $\mathrm{Na}-\mathrm{K}$ bearing silicate was obtained. Previously, Wang and 


\section{$10^{\text {th }}$ International Kimberlite Conference, Bangalore - 2012}

Takahashi (2000), in a study on K-doped KLB-1 peridotite at 10-27 $\mathrm{GPa}$ demonstrated that new Kbearing silicate minerals, named $\mathrm{K}$ phase I, II and III, coexist with mantle minerals. The composition of our $\mathrm{K}$ phase is different from the published results of Wang and Takahashi (2000) but close to the $\mathrm{K}_{2} \mathrm{Ca}_{6} \mathrm{Si}_{4} \mathrm{O}_{15}$ phase, which was classified as a mixed anion silicate containing insular $\left[\mathrm{SiO}_{4}\right]$-groups and $\left[\mathrm{Si}_{2} \mathrm{O}_{7}\right]$-dimers in the ratio 2:1 (Arroyabe et al., 2009). The crystallochemical formula of this phase, calculated on the basis of 12 cations, can be written as $(\mathrm{K}, \mathrm{Na})_{2.213}(\mathrm{Mg}, \mathrm{Ca}, \mathrm{Fe})_{6.012} \mathrm{Si}_{3.776} \mathrm{O}_{14.669}$.
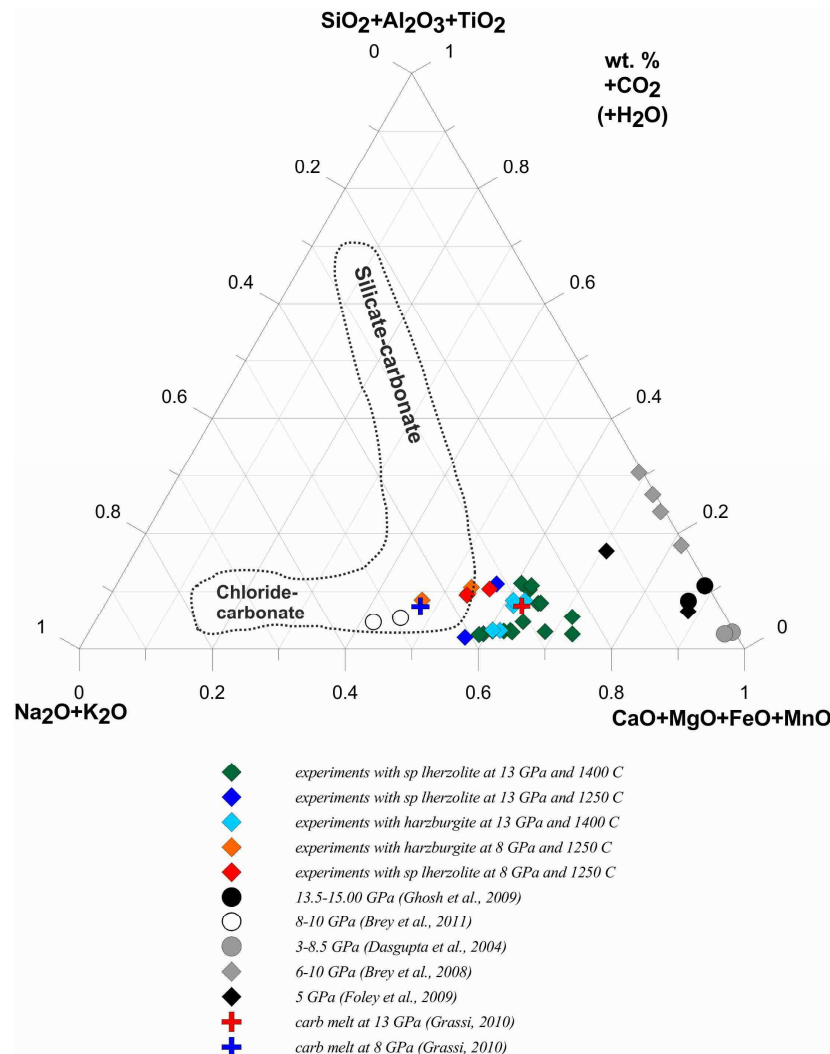

Fig. 3. $\mathrm{SiO}_{2}+\mathrm{Al}_{2} \mathrm{O}_{3}+\mathrm{TiO}_{2}-\mathrm{CaO}+\mathrm{MgO}+\mathrm{FeO}+\mathrm{MnO}-\mathrm{Na}_{2} \mathrm{O}+\mathrm{K}_{2} \mathrm{O}$ (in wt. \%) ternary projection for carbonatite melts; composition of melts from this study is compared with carbonate-rich melt/fluid inclusions in diamonds (dotted area after Klein-BenDavid et al., 2007) and partial melts from carbonated peridotites (Brey et al., 2008) with increased alkali content (Foley et al., 2009; Ghosh et al., 2009; Brey et al., 2011) and from carbonated eclogites (Dasgupta et al., 2004)

\section{DISCUSSION}

Sediment derived carbonatite melts are efficient metasomatic agents transforming mantle assemblages in high-alkali mantle domains with carbon present in the form of carbonates/melts or diamond/graphite depending on the oxygen fugacity which is ultimately a result of the carbonatite/mantle mass ratio of the reactive volume under consideration. In the vicinity of the carbonatite melt source or in regions of high carbonatite flow, mantle lherzolites and harzburgites are transformed into carbonated wherlites. Carbonates in such a subsolidus assemblage become progressively more potassium-rich as the melt solidifies. Garnet proportions increase in comparison to modal mineral abundances in spinel lherzolite at pressures and temperatures close to our study; harzburgites equilibrated with our carbonatite melts do not differ much to that of pyrolite (Irifune and Ringwood 1987 a, b; Green and Ringwood, 1970). Compositions of silicates shift into the region of eclogite affinity with the increasing $\mathrm{CaO}, \mathrm{Fe}_{2} \mathrm{O}_{3}$, and $\mathrm{TiO}_{2}$ contents in garnet and clinopyroxene.

Approximate solidi of K-rich carbonated peridotites comprising regions of metasomatized mantle, as would result from the infiltration of sediment derived carbonatites, are approximately $200{ }^{\circ} \mathrm{C}$ below the mantle adiabat at $13 \mathrm{GPa}$ and close to adiabatic temperatures at $8 \mathrm{GPa}$, consistent with the experimental determinations of solidus location for K-rich carbonated peridotites (Ghosh et al., 2009; Brey et al., 2011). This suggests that cabonatites would travel within the mantle until they are either redox frozen (see below) or reach relatively cold lithospheric mantle keels.

Mineral assemblages change profoundly in the regions, where metal-bearing mantle dominates over carbonatite melt. At oxygen fugacities slightly below the IW buffer, the carbon of the carbonatite melt converts completely into diamond, which could coexist at such conditions with periclase, olivine, garnet, clinopyroxene, and alkali-bearing silicates, such as phase $\mathrm{X}$ or the K-bearing phase, obtained in this study.

\section{REFERENCES}

Akaogi M., Akimoto S. (1979): High-pressure equilibria in a garnet lherzolite, with special reference to $\mathrm{Mg}^{2+}-\mathrm{Fe}^{2+}$ partitioning among constituent minerals. Physics of the Earth and Planetary Interiors 19, 31-51.

Arroyabe E., Kaindl R., Többens D.M., Kahlenberg V. (2009): $\mathrm{K}_{2} \mathrm{Ca}_{6} \mathrm{Si}_{4} \mathrm{O}_{15}$ - structural and spectroscopical studies on a mixed tetrahedral-octahedral framework. Journal of Solid State Chemistry 182, 3254-3261.

Avanzinelli R., Elliott T., Tommasini S., Conticelli S. (2008): Constraints on the genesis of potassium-rich Italian volcanic rocks from U/Th disequlibrium. Journal of Petrology 49 (2), 195-223.

Brey G.P., Bulatov V.K., Girnis A.V., Lahaye Y. (2008): Experimental melting of carbonated peridotite at 6-10 GPa. Journal of Petrology 49 (4), 797-821.

Brey G.P., Bulatov V.K., Girnis A.V. (2011). Melting of Krich carbonated peridotite at 6-10 GPa and the stability of K-phases in the upper mantle. Chemical Geology 281, 333-342. 


\section{$10^{\text {th }}$ International Kimberlite Conference, Bangalore - 2012}

Dasgupta R., Hirschmann M.M., Withers A.C. (2004). Deep global cycling of carbon constrained by the solidus of anhydrous, carbonated eclogite under upper mantle conditions. Earth and Planetary Science Letters 227, 73-85.

Dobson D.P., Jones A.P., Rabe R., Sekine T., Kurita K., Taniguchi T., Kondo T., Kato T., Shimomura O., Urakawa S. (1996): In-situ measurements of viscosity and density of carbonate melts at high pressure. Earth and Planetary Science Letters 143, 207-215.

Foley S.F., Yaxley G.M., Rosenthal A., Buhre S., Kiseeva E.S., Rapp R.P., Jacob D.E. (2009): The composition of near-solidus melts of peridotite in the presence of $\mathrm{CO}_{2}$ and $\mathrm{H}_{2} \mathrm{O}$ between 40 and 60 kbar. Lithos $112 \mathrm{~S}$, 274-283.

Frost D.J. (2003): $\mathrm{Fe}^{2+}-\mathrm{Mg}$ partitioning between garnet, magnesiowüstite and $(\mathrm{Mg}, \mathrm{Fe})_{2} \mathrm{SiO}_{4}$ phases of the transition zone. American Mineralogist 88, 387-397.

Ghosh S., Ohtani E., Litasov K.D., Terasaki H. Solidus of carbonated peridotite from 10 to $20 \mathrm{GPa}$ and origin of magnesiocarbonatite melt in the Earth's deep mantle. Chemical Geology 262, 17-28.

Grassi D. (2010): Melting of subducted carbonated pelites from 5 to $23 \mathrm{GPa}$ : alkali-carbonatites, mantle metasomatism, and element recycling. $\mathrm{PhD}$ thesis, Diss. ETH No 18995, Zürich.

Grassi D., Schmidt M.W. (2011a): Melting of carbonated pelites at 8-13 GPa: generating K-rich carbonatites for mantle metasomatism. Contributions to Mineralogy and Petrology 162, 169-181.

Grassi D., Schmidt M.W. (2011b): The melting of carbonated pelites from 70 to $700 \mathrm{~km}$ depth. Journal of Petrology 52 (4), 765-789.

Green D.H., Ringwood A.E. (1970): Mineralogy of peridotitic compositions under upper mantle conditions. Physics of Earth and Planetary Interiors 3, 359-371.

Irifune T., Ringwood A.E. (1987a): Phase transformations in a harzburgitic composition to $26 \mathrm{GPa}$ : implications for dynamical behavior of the subducting slab. Earth and Planetary Science Letters 86, 365-376.

Irifune T., Ringwood A.E. (1987b): Phase transformations in primitive MORB and pyrolite compositions to $25 \mathrm{GPa}$ and some geophysical implications. In High Pressure Research in Mineral Physics (eds. M.H. Manghnani and Y. Syono), pp. 231-242, American Geophysical Union, Washington, DC.

Klein-BenDavid O., Logvinova A.M., Schrauder M., Spetsius Z.V., Weiss Y., Hauri E.H., Kaminsky F.V., Sobolev N.V., Navon O. (2009): High-Mg carbonatitic microinclusions in some Yakutian diamonds - a new type of diamond forming fluid. Lithos 112, 648-659.

Mukhopadhyay D., Basu S., Holdaway M.J.A. (1993): A discussion of Margules-type formulations for multicomponent solutions with a generalized approach. Geochimica et Cosmochimica Acta 57, 277-283.

Salters V. and Stracke A. (2004): Composition of the depleted mantle. Geochemistry, Geophysics, Geosystems 5(5), 1525-2027.
Schulze D.J. (2003): A classification scheme for mantlederived garnets in kimberlite: a tool for investigating the mantle and exploring for diamonds. Lithos 71, 195213.

Simons B., Sharma S.K. (1983): Crystal data for synthetic $\mathrm{K}_{2} \mathrm{Mg}\left(\mathrm{CO}_{3}\right)_{2}$. Journal of Applied Crystallography 16. 143.

Sobolev N.V., Logvinova A.M., Zedgenizov D.A., Seryotkin Y.V., Yefimova E.S., Floss C., Taylor L.A. (2004): Mineral inclusions in microdiamonds and microdiamonds form kimberlites of Yakutia: a comparative study. Lithos 77, 225-242.

Stracke A, Hofman AW, Hart S (2005): FOZO, HIMU, and the rest of the mantle zoo. Geochemistry, Geophysics, Geosystems 6, Q05007, doi:10.1029/2004GC000824.

Swatzendruber L.J. (1984): The Fe-Ir (iron-iridium) system. Bulletin of Alloy Phase Diagrams 5, 48-52.

Takahashi E. (1986): melting of peridotite KLB-1 up to 14 GPa: implications on the origin of peridotite upper mantle. Journal of Geophysical Research 91 (B9), 9367-9382.

Taylor L.A., Keller R.A., Snyder G.A., Wang W., Carlson W.D., Hauri E.H., Mccandless T., Kim K.-R., Sobolev N.V., Bezborodov S.M. (2000): Diamonds and their mineral inclusions, and what they tell us: a detailed "pull-apart" of a diamondiferous eclogite. International Geology Review 42, 959-983.

Thomsen T.B., Schmidt M.W. (2009): Melting of carbonaceous pelites at 2.5-5.0 GPa, silicatecarbonatite liquid immiscibility, and potassium-carbon metasomatism of the mantle. Earth and Planetary Science Letters 267, 17-31.

Wang W., Takahashi E. (2000): Subsolidus and melting experiments of K-doped peridotite KLB-1 to $27 \mathrm{GPa}$ : its geophysical and geochemical implications. Journal of Geophysical Research 105 (2), 2855-2868.

Wang W., Gasparik T. (2001): Metasomatic clinopyroxene inclusionsin diamonds from the Lianong province, China. Geochimica et Cosmochimica Acta 65 (4), 611620.

Woodland A.B., O'Neill H.St.C. (1997): Thermodynamic data for Fe-bearing phases obrained using nobel metal alloys as redox sensors. Geochimica et Cosmochimica Acta 61 (20), 4359-4366.

Zedgenizov D.A., Kagi H., Shatsky V.S., Sobolev N.V. (2004). Carbonatitic melts in cuboid diamonds from Udachnaya kimberlite pipe (Yakutia): evidence from vibrational spectroscopy. Mineralogical Magazine 68, 61-73. 